thirds of its time, and utilising also, as I have above explained, the more rapid of the descending currents, the bird can more than sustain itself. It can at will glide to windward at the rate of fifteen miles an hour against the breeze, losing of elevation only one in twenty.

L'Ermitage, Hyères (Var), France, April 28 R. Courtenay

\section{Flight of Crows}

I CAN corroborate the observation of Mr. Murphy as to the oblique flight of crows. When I have seen them so flying there has always been a cross current, and they have merely kept their heads a little to the wind.

Cambridge

Thos. McKenny Hughes

\section{Sheet Lightning}

Du choc des opinions jaillit la vérité. I still adhere to your assertion that sheet lightning is not, at least in most cases, the mere reflection of a common but distant storm. On the highlands of Ethiopia, in the years 1842 to 1848 I was diligertly engaged in investigating the electrical phenomena so frequent in that region. The details of my observations were printed in 1858 by the French Institute, and I have published again my, results in my "Observations relatives à la Physique du Globe" (Paris, 1873). The following cases may be of interest :-

Near the zenith eight successive flashes of lightning were seen 2I seconds before their thunder, which lasted exactly I 2 seconds. Another day it lasted $24^{\circ} 4$ s. thirty successive times, and, as previously, without any rain. My greatest observed interval was III'2S., corresponding to a distance of 38,500 metres, \&c.

I have seen more than once straight or zigzag lightning unaccompanied by thunder. One afternoon it went to and fro twice between two horizontal cloud banks, and ended in sheet lightning which illuminated, not the lower dark bank, but only the under surface of the upper cloud. I have observed frequently thunder without lightning and lightning without thunder.

When in Adwa I recorded silent sheet lightning towards Gondar, 240 kilometres distant, where a violent storm was raging at the same time. Before leaping to a hasty conclusion, let us hear a case bearing pointedly to the opposite opinion : in 1845, at Saga (latitude $8^{\circ} \mathrm{II}^{\prime}$ ), a semi-transparent fog which had mantled over the valley, and could not be more than $35 \mathrm{co}$ metres distant, gave out a flash of sheet lightnir $\mathrm{g}$ without thunder.

Although my numerous observations have given me a strong bias in favour of your opinion, I do not wish to impose it on reluctant philosophers, but suggest the following system to clear up the question :--Let two observers, $\mathrm{A}$ and $\mathrm{B}, 40$ or 50 miles asunder, mention instances of lightning seen in each other's true bearing. If they can also secure the help of a third observer located on or near the straight line from $A$ to $B$, and who can watch in two opposite directions, many important results may be obtained.

AnTOINE D'ABBADIE

Paris, May 5

\section{The American Trotting-Horse}

MR. BREWER's memoir on the evolution of the breed of the American trotting-horse (NATURE, vol. xxvii. p. 609), and the statistical tables that accompany it, are full of interest, but I only propose now to concern myself with the latter, which may be easily and usefully discussed by employing a statistical method that I have long advocated. In explanation I will begin by extracting the final terms of four of the lines of his table, as follows :-

\begin{tabular}{|c|c|c|c|c|c|c|c|c|c|}
\hline 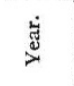 & 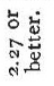 & 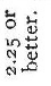 & 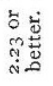 & 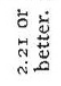 & 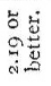 & 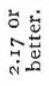 & 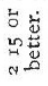 & 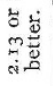 & 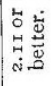 \\
\hline $\begin{array}{l}1871 \\
1874 \\
1877 \\
1880\end{array}$ & 99 & $\begin{array}{l}40 \\
98\end{array}$ & $\begin{array}{l}17 \\
40 \\
105\end{array}$ & $\begin{array}{r}12 \\
16 \\
51 \\
106\end{array}$ & $\begin{array}{r}6 \\
\text { II } \\
19 \\
41\end{array}$ & $\begin{array}{r}\mathbf{I} \\
5 \\
8 \\
14\end{array}$ & $\begin{array}{l}\text { I } \\
2 \\
6\end{array}$ & 2 & I \\
\hline
\end{tabular}

The meaning of these entries are, that in the year $187 \mathrm{I}$ there were 99 horses that could trot a mile in 2 minutes 27 seconds, or less; that in the same year there were 40 that could trot it in 2 minutes 25 seconds, or less; and so on. Their significance is that the rate per mile of the hundred fastest American trottinghorses has become 2 seconds faster in each successive period of 3 years, beginning with $187 \mathrm{I}$, and ending with 1880 ; also that the relative speed of the hundred fastest horses in each year is closely the same, though their absolute speed differs.

We may read the table in another way. If the number of horses that can run a mile in 2 minutes 27 seconds or less is 99 , we may infer without risk of sensible error that the 99 th horse in the order of running accomplishes a mile in that time exactly, because the rooth horse certainly takes a longer time, and it is statistically incredible that the rate of the $99 \mathrm{th}$ and of the rooth horses should differ by more than a barely perceptible interval. For the same reason we may infer that the 4 oth horse in that same year runs a mile in 2 minutes 25 seconds, and so on. We can now draw curves, and by graphical interpolation find with the greatest facility the mile rate of the horse in any order of running in any year that we please to select. I have selected the Iooth, 5oth, 20th, and Ioth horse respectively for each year beginning with 1874 , when we are informed that the returns first begin to te accurate, and have thrown the results into the following simple table. The curves obviously required a little smoothing here and there, and in three or four places the readings have been thereby modified by one or two tenths of a second. Otherwise they are given directly from the rough plottings.

Number of Srconds and Tenths of Seconds in Excess of Two Minutes that are required for Running One Mile by the Horses whose Order in the Rate of Running in each Year is given at the Top of the Columns

\begin{tabular}{|c|c|c|c|c|}
\hline$Y_{\text {ear. }}$ & rooth. & 5oth. & 2oth. & roth. \\
\hline I 874 & $25 \cdot \mathrm{I}$ & 23.4 & 20.5 & 18.8 \\
\hline 1875 & $24 \cdot I$ & 22.5 & 19.9 & $18 \cdot 2$ \\
\hline 1876 & 23.5 & $21 \cdot 6$ & 19.5 & 17.7 \\
\hline 1877 & 22.9 & 210 & $190^{\circ}$ & $17 \%$ \\
\hline 1878 & $22 \cdot I$ & $20 \cdot 2$ & 18.5 & $170^{\circ}$ \\
\hline 1879 & $21 \cdot 3$ & 19.6 & $180^{\circ}$ & 16.6 \\
\hline 1880 & 20.8 & 193 & 17.6 & $16^{\circ} \mathrm{C}$ \\
\hline I $88 \mathrm{I}$ & $20^{\circ} 4$ & 18.8 & $17 \cdot 2$ & 15.7 \\
\hline I 882 & $19^{\circ} 9$ & 18.4 & $17^{\circ} \mathrm{O}$ & 15.4 \\
\hline $\left.\begin{array}{c}\text { Anticipated } \\
\text { I } 890\end{array}\right\}$ & 16.8 & 15.5 & $14 \%$ & 134 \\
\hline
\end{tabular}

Mem. - The first horse runs the mile in about 5 or 6 seconds less than the tenth horse.

It will be found on plotting the figures in the verlical columins into curves, that they run with much regularity and differ little from straight lines. The general conclusion to be derived from them is that the improvement of the running shows as yet little tendency to slacken, though no doubt if the number of horses bred for trotting ceased to increase yearly at the same large rate as hitherto, it might do so. Supposing, however, the conditions to be maintained, I should anticipate that in 1890 there will be about 15 horses that will run a mile in 2 minutes I 5 seconds or less, and that the fastest horse of that year will run a mile in about 2 minutes 8 seconds.

\section{Francis GaLton}

\section{The Shapes of Leaves}

Mr. Grant Allen's papers in NATURe will evidenly serve to direct attention to a most interesting subject which hitherto appears to have been much neglected. Every contribution of observed facts may tend to throw further light upon it, and I therefore venture to remark that one cause of the frequently filiform character of the leaves of waterplants appears to be the elongating action exercised upon the cells by the pressure of a rapid current of water, since it is obvious that growth must take place in the direction of the least resistance. With a radiate-veined leaf the tendency must be towards lateral pressure, which would compress and elongate, and so give a linear form to the leaf-cells. I have been much interested to observe that on the seashore, in places where Fuci are exposed to this action by the ebbing tide, as when growing on the edge of a large boulder or hanging over its sides, the fronds and even the receptacles become unusually elongated. 